Dochody imigrantów i ich transfery zagraniczne, red. Magdalena Butrymowicz,

Piotr Kroczek, Kraków 2019, s. 57-75 (Biblioteczka Prawa 3).

DoI: http://dx.doi.org/10.15633/9788374387804.03

Dawid Chaba

OOOO-0002-2385-3466

UNIWERSYTET JAGIELLOŃSKI

\title{
Status uchodźcy jako prawna forma ochrony międzynarodowej cudzoziemców
}

Regulowanie różnorodnych zagadnień odnoszących się do cudzoziemców jest sprawą niezwykle istotną w ramach funkcjonowania każdego państwa, przy czym w ostatnich latach dotyczy to w szczególności Unii Europejskiej. Jest to związane przede wszystkim z kryzysem migracyjnym, który został wywołany wybuchem wojen domowych w Syrii i Libanie czy powstaniem i rozwojem tzw. Państwa Islamskiego. Kryzys ten doprowadził do masowych migracji ludności z terenu Afryki oraz Azji na kontynent europejski. Mieszkańcy Syrii oraz innych państw Bliskiego Wschodu poszukują bowiem na terenie Europy nowych perspektyw życiowych, niejednokrotnie uciekając przed prześladowaniami w ich własnych ojczyznach, zagrażającymi nawet ich życiu1. Co istotne, praktycznie corocznie, począwszy od 2011 roku, a więc od momentu uwidocznienia się kryzysu migracyjnego, w znaczny sposób zwiększa

1 M. Duszczyk, Kryzys migracyjny 2015/2016, iminteg.uw.edu.pl/pdf/Maciej-Duszczyk-Kryzys-migracyjny-2015-2016.pdf, s. 1 (4.10.2017). 
się wielkość migracji na teren Europy. Warto zaznaczyć, że w 2015 roku do ue przybyło aż 832 tys. migrantów i było to ponad 4 razy więcej niż w 2014 roku (200 tys. osób)². Warto zauważyć, że liczby te dotyczą jedynie tych migrantów, którzy przybyli na teren Wspólnoty w sposób legalny. Według szacunków należy do nich doliczyć jeszcze około 1,8-2,o mln osób, które udały się do państw członkowskich ue wyłącznie w celu uzyskania ochrony bądź, wykorzystując ogromne zamieszanie związane z kryzysem migracyjnym, dostały się na teren UE w sposób nielegalny3. Wprawdzie w 2016 roku liczba legalnych i nielegalnych imigrantów zmniejszyła się do poziomu 504 tys. (był to wynik głównie uszczelnienia granic w krajach Półwyspu Bałkańskiego oraz parafowania porozumienia między uE i Turcją, zakładającego odsyłanie wszystkich nielegalnych imigrantów z terenu Grecji z powrotem do Turcji) ${ }^{4}$, jednak faktem jest, że nadal na teren Wspólnoty przybywa bardzo duża liczba cudzoziemców. Dane te pokazują, jak ogromnym problemem dla Wspólnoty są obecnie kwestie odnoszące się do cudzoziemców i podejmowania przez nich migracji na tereny krajów należących do Unii.

Z tematyką dotyczącą migracji cudzoziemców do UE w nierozerwalny sposób powiązane są kwestie dotyczące nadawania im statusu uchodźcy. Jak wskazują bowiem dane statystyczne, większość cudzoziemców przybywających na tereny państw członkowskich Unii to osoby, które uciekły ze swoich ojczyzn z powodów politycznych (obawa przed prześladowaniami i skutkami działań militarnych) i w krajach docelowych starają się o nadanie im statusu uchodźcy ${ }^{5}$. Przykładowo, do 12 stycznia 2015 roku na terenie Syrii zarejestrowano ponad 3,2 mln

2 Niekontrolowane migracje do Unii Europejskiej - implikacje dla Polski, red. P. Sasnal, Polski Instytut Spraw Międzynarodowych, Warszawa 2015, s. 11.

3 M. Duszczyk, Kryzys..., dz. cyt., s. 9.

4 www.wsensie.pl/swiat/20303-w-ostatnim-roku-do-europy-przedostalo-sie-o-2-3-mniej-imigrantow-niz-w-roku-2015 (4.10.2017).

5 Niekontrolowane..., dz. cyt., s. 11. 
uchodźców, a w samym 2014 roku złożyli oni w UE ponad 126 tys. wniosków o nadanie statusu uchodźcy ${ }^{6}$. Z uwagi na to tak ważne staje się omawianie kwestii dotyczących statusu uchodźcy.

W pracy główna uwaga zostanie skupiona na analizie kwestii związanych $\mathrm{z}$ tym, kim według prawa międzynarodowego oraz polskiego jest uchodźca, jakie warunki muszą być spełnione przez cudzoziemca, by mógł się ubiegać o nadanie statusu uchodźcy, jak wygląda procedura związana $\mathrm{z}$ uzyskiwaniem tego statusu, jakie formy pomocy są w jej ramach przewidziane oraz jak duża liczba cudzoziemców otrzymała status uchodźcy. W pracy postawiono tezę, iż status uchodźcy jest jedną z najważniejszych form międzynarodowej ochrony cudzoziemców, co wydaje się ważne ze względu na fakt, iż w przeciągu ostatnich kilku lat liczba wniosków składanych w związku z chęcią otrzymania takiego statusu znacznie wzrosła na terenie Polski i Europy.

\section{Definicja uchodźcy}

Analizując podstawowe zagadnienia dotyczące statusu uchodźcy, trzeba w pierwszej kolejności określić, kogo prawo międzynarodowe oraz prawo polskie uznaje za uchodźcę. Podstawą uregulowań w tym zakresie są przepisy, które zostały zawarte w Konwencji dotyczącej statusu uchodźców, sporządzonej w Genewie dnia 28 lipca 1951 roku7, i uzupełnione zapisami umieszczonymi w Protokole dotyczącym statusu uchodźców, sporządzonym w Nowym Jorku dnia 31 stycznia 1967 roku$^{8}$. Przepisy te mówią, że za uchodźcę należy uznać każdą osobę, która z powodu

6 O. Łachacz, Obraz statystyczny napływu osób poszukujących ochrony międzynarodowej do Unii Europejskiej w kontekście rozwoju Wspólnego Europejskiego Systemu Azylowego, [w:] Uchodźcy - nowe wyzwania dla bezpieczeństwa europejskiego na tle standardów praw człowieka, red. W. Pływaczewski, M. Ilnicki, Olsztyn 2015, s. 29.

7 Dz.U. 1991 r., nr 119, poz. 515.

8 Dz.U. 1991 r., nr 119, poz. 517. 
uzasadnionej obawy przed możliwością doznania prześladowań z powodu swojej narodowości, rasy, przynależności do konkretnej grupy społecznej, przekonań politycznych czy religii:

a) przebywa poza granicami państwa, którego jest obywatelem, i nie może bądź nie chce korzystać z ochrony oferowanej przez to państwo (taka osoba może posiadać obywatelstwa kilku państw i w sytuacji, gdy nie skorzysta ona z ochrony oferowanej przez jakiekolwiek spośród nich, nie można jej odmówić w innych krajach ochrony pod postacią nadania statusu uchodźcy), bądź

b) w przypadku nieposiadania obywatelstwa żadnego państwa nie może lub nie chce powrócić do państwa będącego jej stałym miejscem zamieszkania ${ }^{9}$.

Co istotne, według stanowiska zaprezentowanego przez UNHCR (United Nations High Commissioner for Refugees, czyli Wysokiego Komisarza Narodów Zjednoczonych do spraw Uchodźców) w definicji uchodźcy umieszczonej w Konwencji Genewskiej zostały zawarte trzy klauzule - włączenia, wyłączenia oraz ustania ${ }^{10}$. Klauzula włączenia ustala kryteria, które muszą zostać wypełnione, by dana osoba mogła zostać uznana za uchodźcę, tym samym stwarzając jej warunki do starania się o nadanie statusu uchodźcy. Klauzula ta, w przeciwieństwie do dwóch pozostałych, ma charakter pozytywny, formułując wymogi, na podstawie których możliwe staje się ustalenie wspomnianego statusu ${ }^{11}$. Do wymogów tych zalicza się w szczególności istnienie uzasadnionej obawy przed prześladowaniem danej osoby z powodów politycznych czy religijnych oraz przebywanie przez nią poza granicami swojego

9 Art. 1 lit. A pkt 2 Konwencji dotyczącej statusu uchodźców; art. 1 ust. 2 Protokołu dotyczącego statusu uchodźców.

10 Zasady i tryb ustalania statusu uchodźcy: zgodnie z Konwencja dotyczaca statusu uchodźcy z 1951 r. oraz Protokołem dodatkowym do niej z 1967 r. Podręcznik, red. I. Kurz, Warszawa 2007, s. 15.

11 Zasady i tryb ustalania statusu..., dz. cyt., s. 15. 
macierzystego państwa ${ }^{12}$. Należy dodać, że osoby kwalifikowane jako uchodźcy w ramach klauzuli włączenia określa się jako uchodźców statutowych $^{13}$, konwencyjnych ${ }^{14}$ bądź historycznych ${ }^{15}$.

Klauzula wyłączenia wymienia z kolei okoliczności, po których wystąpieniu nie jest możliwe nadanie danej osobie statusu uchodźcy (nawet po wypełnieniu przez nią wymogów wchodzących w zakres klauzuli włączenia). Klauzula ta wskazuje kategorie osób, które nie mogą otrzymać statusu uchodźcy. Zaliczono do nich:

a) uchodźców, którzy zostali objęci ochroną bądź pomocą ze strony organów bądź agencji oNZ innych niż UNHCR,

b) osoby, które w kraju docelowym otrzymały większość praw przysługujących obywatelom tego kraju, ale nie otrzymały jego obywatelstwa,

c) osoby, które dokonały zbrodni przeciwko pokojowi czy ludzkości bądź zbrodni wojennej, lub te, które są winne dokonania czynów sprzecznych z celami i zasadami Narodów Zjednoczonych, w związku z czym nie zasługują na objęcie ochroną międzynarodową ${ }^{16}$.

Klauzula ustania natomiast dotyczy przypadków, w których osoba uznana za uchodźcę przestaje nim być. Wśród przypadków tych jest:

a) dobrowolne zwrócenie się przez tę osobę o ochronę w państwie, którego jest obywatelem,

12 Art. 1 lit. A pkt 2 Konwencji dotyczącej statusu uchodźców.

13 Zasady i tryb ustalania statusu..., dz. cyt., s. 16.

14 A. Florczak, Uchodźstwo, [w:] Organizacje międzynarodowe $w$ działaniu, red. A. Florczak, A. Lisowska, Wrocław 2014, s. 377.

15 B. Wierzbicki, Sytuacja prawna uchodźcy w systemie międzynarodowej ochrony praw człowieka, Białystok 1993, s. 35.

16 Art. 1 lit. F Konwencji dotyczącej statusu uchodźców. Zob. też: A. Duffy, Expulsion to Face Torture? Non-refoulement in International Law, „International Journal of Refugee Law" (2008), nr 3, s. 375-377; S. Sivakumaran, Exclusion from Refugee Status: The Purposes and Principles of the United Nations and Article $1 F(c)$ of the Refugee Convention, „International Journal of Refugee Law” (2014), nr 1, s. 350-381. 
b) ponowne dobrowolne przyjęcie przez nią utraconego wcześniej obywatelstwa danego państwa,

c) przyjęcie nowego obywatelstwa i korzystanie z ochrony w państwie, którego obywatelstwo zostało przez tę osobę przyjęte,

d) ponowne dobrowolne osiedlenie się przez nią w państwie, które opuściła, bądź poza którego granicami przebywała w obawie przed prześladowaniami,

e) niemożność dłuższego odmawiania przez daną osobę możliwości korzystania z ochrony państwa, którego obywatelstwo ta osoba posiada, na co ma wpływ ustanie warunków, w związku z którymi uznano tę osobę za uchodźcę

Należy dodać, że w Konwencji Genewskiej zawarte były również klauzule geograficzna (państwa będące stronami Konwencji mogły ograniczać swoje zobowiązania wyłącznie wobec uchodźców europejskich) oraz czasowa (dotyczyła osób, które zostały uznane za uchodźców przed 1 stycznia 1951 roku, a więc przed datą rozpoczęcia działalności przez $\mathrm{UNHCR}^{18}$ ). Zostały one jednak usunięte po wydaniu Protokołu Nowojorskiego ${ }^{19}$.

Warto tutaj zaznaczyć, że termin „uchodźca” może być analizowany nie tylko w ujęciu prawnym, ale również ogólnym ${ }^{20}$. W tym przypadku zaznacza się np., że uchodźca to każda osoba, która opuszcza własny kraj z przyczyn o charakterze politycznym, religijnym bądź ekonomicznym. Podkreśla się zarazem, że do czynników zmuszających uchodźców do opuszczenia dotychczasowego kraju zamieszkania należą nie tylko te,

17 Art. 1 lit. F Konwencji dotyczącej statusu uchodźców. Zob. też: A. Fermus-Bobowiec, Udzielanie ochrony międzynarodowej cudzoziemcom na terytorium Rzeczypospolitej Polskiej, „Studia Iuridica Lublinensia” (2016), nr 4, s. 29.

18 R. J. Mejsak, System ochrony uchodźców w wymiarze uniwersalnym-perspektywa instytucjonalnoprawna, „Studia Podlaskie” (2012), t. xx, s. 273.

19 K. Cenda-Miedzińska, Prawne i społeczne aspekty bezpieczeństwa uchodźców, „Colloquium Wydziału Nauk Humanistycznych i Społecznych” (2012), nr 3, s. 149.

20 B. Wierzbicki, Uchodźcy w prawie międzynarodowym, Warszawa 1993, s. 9. 
które zostały spowodowane przez człowieka (prześladowania, konflikty zbrojne), ale również czynniki przyrodnicze (np. klęski żywiołowe) ${ }^{21}$. Ważne jest ponadto to, że w znaczeniu ogólnym nie wyodrębnia się uchodźców wewnętrznych, a więc tych, którzy wprawdzie opuścili swoje miejsce zamieszkania, ale nadal pozostają w granicach jednego państwa. W ten sposób podkreśla się, że uchodźca to każda osoba, która wymaga pomocy i ochrony w związku z ucieczką z ojczystego regionu bądź kraju²2.

Należy jeszcze tutaj dodać, że w polskim prawie nie ma definicji uchodźcy. Jest to niewątpliwie związane z tym, że Polska zaimplementowała zapisy znajdujące się w Konwencji Genewskiej. W ten sposób wiążące dla niej są uregulowania dotyczące również istoty tego, kim jest uchodźca. Jedynie w Ustawie z dnia 13 czerwca 2003 roku o udzielaniu cudzoziemcom ochrony na terytorium Rzeczypospolitej Polskiej ${ }^{23}$ (zw. uuco) zawarto definicję uchodźcy mandatoryjnego, stwierdzając, że jest nim cudzoziemiec uznany za uchodźcę przez UNHCR ${ }^{24}$. Poza uchodźcami mandatoryjnymi (mandatowymi) oraz statutowymi można jeszcze mówić o uchodźcach wewnętrznych oraz uchodźcach de facto (osoby, które nie mogą zostać zidentyfikowane jako uchodźcy konwencyjni, gdyż nie żywią obaw przed prześladowaniami, i nie mogą wrócić do swojej ojczyzny ze względu na trwające w niej konflikty) ${ }^{25}$.

\section{Prawne podstawy uzyskiwania przez cudzoziemców statusu uchodźcy}

Jeśli chodzi o definicję statusu uchodźcy, to znajduje się ona w uuco. W ustawie tej zaznaczono, że

\footnotetext{
21 A. Florczak, Uchodźstwo..., dz. cyt., s. 375.

22 B. Kowalczyk, Polski system azylowy, Wrocław 2014, s. 106.

23 Tekst jedn. Dz.U. 2016 r., poz. 1836 [dalej: uuco].

24 Art. 2 pkt 12 uuco.

25 A. Florczak, Uchodźstwo..., dz. cyt., s. 377.
} 
cudzoziemcowi nadaje się status uchodźcy, jeżeli na skutek uzasadnionej obawy przed prześladowaniem w kraju pochodzenia z powodu rasy, religii, narodowości, przekonań politycznych lub przynależności do określonej grupy społecznej nie może lub nie chce korzystać z ochrony tego kraju. Status uchodźcy nadaje się także małoletniemu dziecku cudzoziemca, który uzyskał status uchodźcy w Rzeczypospolitej Polskiej, urodzonemu na tym terytorium ${ }^{26}$.

Przy tym zarówno w doktrynie, jak i orzecznictwie uznaje się zwykle, że uzasadniona obawa przed prześladowaniem składa się z dwóch komponentów: subiektywnego, a więc odczuwania przez daną osobę obawy przed prześladowaniami, które mogą ją dotknąć; obiektywnego, czyli sytuacji obiektywnej, która potwierdza, że obawa ta jest w pełni uzasadniona ${ }^{27}$. Przykładowo, w jednym z wyroków Wojewódzki Sąd Administracyjny w Warszawie uznał, że

osoba ubiegająca się o status uchodźcy winna w sposób nie budzący wątpliwości zasadność tej obawy wykazać. W tym względzie nie wystarcza jedynie subiektywne przekonanie, lecz obawa musi być w pewien sposób zobiektywizowana poprzez odniesienie jej do realiów występujących w kraju pochodzenia osoby ubiegającej się o nadanie jej statusu uchodźcy. Dopiero na tym tle można dokonać właściwej oceny, czy dana osoba ubiegająca się o status uchodźcy rzeczywiście może obawiać się prześladowań ze strony własnego państwa ${ }^{28}$.

26 Art. 13 ust. 1-2 uuco.

27 Orzeczenie Naczelnego Sądu Administracyjnego z dnia 23 lutego 2000 r., sygn, V S.A. 1648/99; A. Gajewska, Definicja uchodźcy uzasadniona obawa przed prześladowaniem (analiza decyzji administracyjnych w sprawie o nadanie statusu uchodźcy), www.hfhrpol.waw.pl/uchodzcy/images/stories/file/Microsoft\%2oWord\%20-\%20 Raport\%20nr\%201-EFU2006.pdf, s. 3 (10.10.2017).

28 Wyrok Wojewódzkiego Sądu Administracyjnego w Warszawie z dnia 16 lipca 2013 r., sygn. IV SA/Wa 682/13. Tak również w Wyroku Wojewódzkiego Sądu Ad- 
Ponadto do warunków nadania danej osobie statusu uchodźcy zalicza się fakt, że prześladowanie, co do którego wystąpienia istnieje uzasadniona obawa, powinno:

a) stanowić poważne naruszenie praw człowieka, w tym szczególnie tych, których uchylenie zgodnie z zapisami znajdującymi się w Konwencji o Ochronie Praw Człowieka i Podstawowych Wolności, sporządzonej w Rzymie dnia 4 listopada 1950 roku $^{29}$, jest niemożliwe (dotyczy to prawa do życia, zakazu tortur i nieludzkiego lub poniżającego traktowania czy karania oraz trzymania w niewoli) ${ }^{30}$,

b) być kumulacją różnych działań bądź zaniechań, które stanowią naruszenie praw człowieka,

c) polegać w szczególności na używaniu przemocy fizycznej, psychicznej czy seksualnej, stosowaniu środków prawnych, policyjnych czy administracyjnych o charakterze dyskryminującym, realizowaniu czynów skierowanych przeciwko osobom ze względu na ich płeć czy małoletniość, karaniu w sposób nieproporcjonalny bądź dyskryminujący, a także wszczynaniu lub prowadzeniu postępowania karnego z powodu odmowy odbycia służby wojskowej podczas konfliktu (jeśli realizacja tej służby miałaby prowadzić do zbrodni) ${ }^{31}$.

Status uchodźcy może być nadany konkretnej osobie tylko po wypełnieniu powyżej opisanych warunków. Zalicza się do nich przede wszystkim fakt, że osoba ta musi zostać uznana za uchodźcę oraz że posiada ona uzasadnione obawy przed prześladowaniem w swoim dotychczasowym kraju zamieszkania. Jak podkreśliła A. Florczak, obawy te mogą

ministracyjnego w Warszawie z dnia 11 stycznia 2013 r., sygn. V sA/Wa 1195/12 czy Wyroku Wojewódzkiego Sądu Administracyjnego w Warszawie z dnia 11 września 2015 r., sygn. IV SA/Wa 1230/15.

29 Dz.U. 1993 r., nr 61, poz. 284.

30 Art. 15 ust. $2 \mathrm{w}$ związku z art. 2-3, art. 4 ust. 1 i art. 7 Konwencji o Ochronie Praw Człowieka i Podstawowych Wolności.

31 Art. 12 ust. 3-4 uuco. 
być związane głównie z naruszaniem praw człowieka i podstawowych wolności, brakiem systemu demokratycznego, konfliktami o charakterze wewnętrznym i międzynarodowym czy zmianami granic ${ }^{32}$.

Trzeba zaznaczyć, że status uchodźcy jest jedną z form międzynarodowej ochrony, cudzoziemców. Zostało to podkreślone m.in. przez $\mathrm{M}$. Górczyńską ${ }^{33} \mathrm{w}$ raporcie $\mathrm{NIK}^{34}$, jak również w samej uuco ${ }^{35}$. Co istotne, z uwagi na to, że Polska jest stroną Konwencji Genewskiej, ciąży na niej obowiązek udzielania ochrony międzynarodowej wszelkim osobom, które wypełniają określone warunki i przesłanki. Objęcie taką ochroną może dojść do skutku nie tylko wtedy, gdy do prześladowań doszło ze strony organów władzy publicznej, ale również wtedy, gdy prześladowania były realizowane przez wszelkie inne podmioty, przed którymi władza nie jest w stanie ochronić swoich obywateli. Ponadto ważne jest, że ochroną międzynarodową może zostać objęta również osoba, względem której ryzyko prześladowań powstało już po opuszczeniu przez nią swojego kraju zamieszkania ${ }^{36}$.

Status uchodźcy stanowi niewątpliwie jedną z najważniejszych form ochrony międzynarodowej, która może być stosowana wobec cudzoziemców. W prawie polskim przwiduje się oprócz niej również ochronę uzupełniającą, udzielenie azylu oraz ochronę czasową.

Ochrona uzupełniająca na terenie Polski jest stosowana wobec osób, którym nie udało się uzyskać statusu uchodźcy i które w przypadku powrotu do swojego kraju zamieszkania mogą zostać narażone na ryzyko doznania poważnej krzywdy z powodu orzeczenia względem nich kary

32 A. Florczak, Uchodźcy..., dz. cyt., s. 374.

33 M. Górczyńska, Status uchodźcy i ochrona uzupełniająca, [w:] Cudzoziemcy w Polsce, red. M. Łysienia, Warszawa 2016, s. 85.

$34 \mathrm{Udzielanie} \mathrm{przez} \mathrm{organy} \mathrm{administracji} \mathrm{ochrony} \mathrm{cudzoziemcom} \mathrm{przebywajacym} \mathrm{na} \mathrm{te-}$ rytorium Rzeczypospolitej Polskiej. Informacja o wynikach kontroli, Najwyższa Izba Kontroli, Warszawa 2015, s. 4.

Art. 3 ust. 1 uuco.

36 M. Górczyńska, Status..., dz. cyt., s. 85-86. 
śmierci lub wykonania egzekucji, stosowania tortur czy nieludzkiego traktowania lub karania, a także powszechnego używania przemocy wobec ludności cywilnej w sytuacji konfliktu zbrojnego ${ }^{37}$.

W literaturze podkreśla się, że azyl to szczególna forma zezwolenia na wjazd i pobyt cudzoziemca na terenie danego państwa, stosowany względem osób, które są dyskryminowane bądź prześladowane za prowadzenie działalności o charakterze politycznym, naukowym czy religijnym bądź za swoje przekonania ${ }^{38}$. Na terenie Polski jest on udzielany wówczas, gdy ,jest to niezbędne do zapewnienia mu [cudzoziemcowi] ochrony oraz gdy przemawia za tym ważny interes Rzeczypospolitej Polskiej"39.

Jeśli chodzi o ochronę czasową, to jest ona udzielana osobom, które przybyły na teren RP ze względu na obcą inwazję, wojnę, w tym domową, konflikty etniczne czy rażące naruszenie praw człowieka. Taka ochrona jest udzielana do momentu powstania możliwości powrotu tych osób do swojego kraju zamieszkania, jednak nie dłużej niż przez 1 rok (w szczególnych przypadkach możliwe jest - jednak nie więcej niż dwa razy - przedłużenie okresu tej ochrony o 6 miesięcy) $)^{40}$.

\section{Wybrane zagadnienia dotyczące uzyskiwania przez cudzoziemców statusu uchodźcy}

Status uchodźcy może zostać nadany cudzoziemcowi wyłącznie po przeprowadzeniu określonej procedury. Przyznanie tego statusu należy do kompetencji Szefa Urzędu do Spraw Cudzoziemców (zajmuje się on również pozbawianiem tego statusu). Odpowiedni wniosek w sprawie

37 Art. 15 uuco.

38 M. Lis, Azyl, [w:] Encyklopedia prawa, red. U. Kalina-Prasznic, Warszawa 2004, s. 40 .

39 Art. 90 ust. 1 uuco.

40 Art. 106 uuco. 
nadania statusu uchodźcy jest składany przez cudzoziemców za pośrednictwem komendantów oddziałów bądź placówek Straży Granicznej. Wniosek jest składany osobiście, przy czym w przypadku małoletniego dziecka czy małżonka może zostać złożony w ich imieniu. We wniosku umieszczane są dane (imię i nazwisko) cudzoziemca oraz ewentualnie dane osobiste jego małżonka i dziecka, a także informacje dotyczące jego ostatniego miejsca zamieszkania, miejsca pracy w kraju pochodzenia, odbycia służby wojskowej, znajomości języków obcych, wyjazdu z kraju pochodzenia, wjazdu i pobytu na teren RP, stanu zdrowia czy prowadzonych względem niego postępowań karnych. Rozpatrzenie wniosku następuje w terminie maksymalnie do 6 miesięcy od jego złożenia (okres ten może zostać wydłużony do 15 miesięcy w sytuacji, gdy np. prowadzona sprawa wykazuje duży stopień skomplikowania bądź gdy jednocześnie z wnioskami o nadanie statusu uchodźcy czy innych form ochrony międzynarodowej występuje spora liczba cudzoziemców). Szef Urzędu do Spraw Cudzoziemców decyduje o tym, czy złożony wniosek jest dopuszczony (nie może on zostać uznany za taki na przykład wtedy, gdy inny kraj członkowski uE udzielił już wnioskodawcy ochrony międzynarodowej) ${ }^{41}$.

Warto dodać, że w czasie prowadzenia postępowania w sprawie rozpatrzenia wniosku o nadanie statusu uchodźcy cudzoziemcom przyznawane jest tymczasowe zaświadczenie tożsamości, które uprawnia ich do pobytu na terenie Polski do zakończenia wspomnianego postępowania $^{42}$. Co więcej, w tym okresie cudzoziemcy mogą również korzystać z pomocy, która jest oferowana w ośrodkach dla cudzoziemców ubiegających się o nadanie statusu uchodźcy. Pomoc ta obejmuje wyżywienie, leczenie czy pokrycie kosztów nauki. Z kolei w sytuacji, gdy dany cudzoziemiec nie może, np. ze względu na zły stan zdrowia,

41 Art. 23-38 uuco.

42 Art. 55 uuco. 
przebywać w takim ośrodku, może mu zostać wypłacone świadczenie pieniężne ${ }^{43}$.

Po uzyskaniu statusu uchodźcy cudzoziemiec posiada szereg praw oraz obowiązków. Jeśli chodzi o prawa, są to:

a) prawo pobytu na terenie RP - cudzoziemiec otrzymuje kartę pobytu i może zostać wydalony z kraju jedynie ze względu na bezpieczeństwo państwowe czy porządek publiczny ${ }^{44}$,

b) prawo do zameldowania i uzyskania numeru PESEL CZy NIP,

c) prawo do wymiany zagranicznego prawa jazdy na dokument krajowy,

d) możliwość odbywania podróży zagranicznych - w ich trakcie uchodźca posługuje się rodzajem dokumentu podróży, który jest określany jako paszport genewski,

e) prawo do podejmowania i realizowania pracy na takich samych zasadach jak obywatele polscy,

f) prawo do podejmowania i realizowania działalności gospodarczej,

g) prawo do otrzymywania świadczeń socjalnych, w tym zasiłków rodzinnych, pielęgnacyjnych i wychowawczych,

h) prawo do odbywania nauki w szkołach podstawowych, ponadpodstawowych i wyższych,

i) możliwość podlegania ubezpieczeniu zdrowotnemu (każdy uchodźca może ubezpieczyć się dobrowolnie w Narodowym Funduszu Zdrowia bądź podlega takiemu obowiązkowi ze względu na realizację umowy o pracę),

j) możliwość ubiegania się o obywatelstwo polskie na korzystniejszych warunkach niż inni cudzoziemcy ${ }^{45}$.

43 D. Sowińska, Geneza wprowadzenia przepisów regulujących formy ochrony cudzoziemców na terytorium RP, „Przegląd Bezpieczeństwa Wewnętrznego” (2012), nr 6, S. 28.

44 Art. 32-33 Konwencji dotyczącej statusu uchodźców.

45 Prawa i obowiązki uchodźców w Polsce, red. T. Sieniow, Lublin 2010, s. 68-118. 
Co istotne, cudzoziemcy, którzy uzyskali status uchodźcy, mają prawo do szerokiej pomocy o charakterze integracyjnym. Jej celem jest przyspieszenie procesu integracji uchodźców ze społeczeństwem polskim. $\mathrm{W}$ jej ramach przez okres 12 miesięcy cudzoziemcom wypłacane jest comiesięczne świadczenie przeznaczone na utrzymanie, tak by mogli się skupić na nauce języka polskiego. Ponadto mogą wziąć udział w różnego rodzaju programach, które pozwolą im na przykład podwyższyć swoje kwalifikacje zawodowe i zdobyć wymarzoną pracę ${ }^{46}$.

Uchodźcy mieszkający na terenie Polski posiadają również szereg obowiązków. Zalicza się do nich w szczególności konieczność nauki języka polskiego oraz aktywnego poszukiwania pracy w celu usamodzielnienia się pod względem finansowym. Warto dodać, że cudzoziemcy, którzy starają się o nadanie statusu uchodźcy, są zobligowani do stawiania się na wywiady statusowe (dotyczą one motywów przyjazdu cudzoziemców do Polski czy ich aktualnej sytuacji rodzinnej i materialnej), udostępniania organom administracyjnym wszelkich dokumentów i dowodów, które potwierdzają okoliczności wskazane we wniosku o nadanie statusu uchodźcy, zawiadamianie o każdej zmianie miejsca pobytu, jak również przebywanie na terenie Polski do czasu podjęcia ostatecznej decyzji w sprawie przyznania statusu uchodźcy ${ }^{47}$.

Warto dodać, że z problematyką dotyczącą nadawania statusu uchodźcy wiąże się szereg praktycznych problemów, które ujawniają się na szeroką skalę również w Polsce. Chodzi przykładowo o to, że nierzadko cudzoziemcy nadużywają procedur związanych ze składaniem wniosków o nadanie statusu uchodźcy. Przepisy nie określają bowiem, jaka maksymalna liczba takich wniosków może zostać złożona przez jedną osobę. Skutkiem tego jest fakt, że wiele osób, zamiast opuścić teren

46 A. Chrzanowska, K. Gracz, Uchodźcy w Polsce. Kulturowo-prawne bariery w procesie adaptacji, Warszawa 2007, s. 160-162.

47 Art. 41 uuco. 
kraju po otrzymaniu negatywnej decyzji odnośnie do nadania statusu uchodźcy, składa kolejny taki wniosek, nabywając ponownie prawa np. do pomocy socjalnej i opieki medycznej. Kolejny problem jest związany z tym, że nierzadko cudzoziemcy, którym nadano w Polsce status uchodźcy, wyjeżdżają do kraju swojego pochodzenia. W ostatnich latach zjawisko to na szerszą skalę uwidacznia się na przykład wśród Czeczeńców. Powoduje to, że konieczne jest wszczynanie spraw o pozbawienie statusu uchodźcy, które bardzo często znacznie się przedłużają ze względu np. na brak kontaktu $z$ danym cudzoziemcem ${ }^{48}$.

Można wspomnieć jeszcze o problemie związanym z czynnikami wpływającymi na podejmowanie przez cudzoziemców decyzji odnośnie do starania się przez nich o status uchodźcy. Chodzi o to, że obecnie coraz częściej cudzoziemcy decydują się na wyjazdy z własnych krajów zamieszkania nie tylko z pobudek politycznych, a więc z obawy przed prześladowaniami, ale również z motywów natury ekonomicznej. Skutkiem tego jest fakt, że wielu cudzoziemców podejmuje próby wykorzystywania ochrony międzynarodowej do stałego osiedlenia się na terenie danego państwa głównie w celach ekonomicznych, związanych np. z chęcią zdobycia dobrze płatnej pracy i polepszenia własnej sytuacji materialnej. Komplikuje to niewątpliwie indywidualną ocenę położenia każdej osoby przebywającej na terenie określonego kraju unijnego, w tym również Polski, i utrudnia uudzielenie pomocy w postaci nadania statusu uchodźcy ${ }^{49}$.

Na koniec warto zauważyć, że w przeciągu ostatnich kilku lat, w dużej mierze z uwagi na wciąż trwający kryzys migracyjny, na terenie Polski i uE znacznie wzrosła liczba cudzoziemców, którzy starają się o nadanie statusu uchodźcy. W całej Wspólnocie w 2015 roku złożono ponad

48 N. Rafalik, Cudzoziemcy ubiegający się o nadanie statusu uchodźcy w Polsce - teoria a rzeczywistość (praktyka), Warszawa 2012, s. 40-49.

49 O. Łachacz, Obraz..., dz. cyt., s. 28. 
1,3 mln wniosków o nadanie statusu uchodźcy. Rok wcześniej takich wniosków było nieco ponad 600 tys., a w 2013 roku ponad 400 tys. ${ }^{50}$. Z kolei w pierwszych trzech kwartałach 2016 roku złożonych zostało aż 950 tys. wniosków ${ }^{51}$. Przy tym charakterystyczne jest to, że zdecydowanie największa liczba wniosków dotyczy terenu Niemiec, co niewątpliwie wiąże się z tym, że cudzoziemcy starają się osiedlić w tym państwie, które może dać im najlepsze perspektywy rozwojowe. Trzeba zaznaczyć, że w 2016 roku ochroną międzynarodową w postaci nadania statusu uchodźcy objęto na terenie Unii aż 710 tys. osób. Stanowi to dwukrotny wzrost w porównaniu do 2015 roku. Najwięcej osób, którym przyznano ten status, pochodziło z terenu Syrii (405 tys.), Iraku (66 tys.) oraz Afganistanu (62 tys.). Przy tym aż ponad 70\% Syryjczyków, którym nadano status uchodźcy, przebywa na terenie Niemiec. To właśnie w tym państwie wydano najwięcej decyzji o przyznaniu tego statusu (445 tys., a więc 3 razy więcej niż w 2015 roku). Na drugim miejscu znalazła się Szwecja (69 tys.), a na trzecim Włochy (35 tys.) ${ }^{52}$.

Jeśli chodzi o Polskę, to trzeba zaznaczyć, że w 2016 roku zostały złożone 4502 wnioski dotyczące objęcia cudzoziemców ochroną międzynarodową (w raportach Szefa Urzędu do Spraw Cudzoziemców nie dokonano podziału na poszczególne formy ochrony, tak więc nie wyszczególniono liczby wniosków dotyczących jedynie nadania statusu uchodźcy). W porównaniu do poprzedniego roku liczba ta była nieco mniejsza, gdyż w 2015 roku złożono 4927 takich wniosków. Z kolei porównując te dane z danymi z 2014 roku, trzeba stwierdzić, że w latach 2015-2016 znacznie wzrosła liczba takich wniosków. W tym właśnie roku bowiem złożono 3402 takich wniosków. W 2016 roku Szef Urzędu

50 M. Duszczyk, Kryzys..., dz. cyt., s. 2.

51 http://m.niezalezna.pl/91488-tylu-uchodzcow-zarejestrowano-juz-w-ue-w-2016-roku (16.10.2017).

52 www.tvn24.pl/wiadomosci-ze-swiata,2/unia-europejska-w-2016-r-przyznano-ochrone-710-tysiacom-migrantow,735179.html (16.10. 2017). 
do Spraw Cudzoziemców status uchodźcy nadał 108 osobom. Wśród nich najwięcej było Syryjczyków (40), Ukraińców (16) oraz Rosjan (10). W porównaniu z 2015 Czy 2014 rokiem był to znaczny spadek liczby pozytywnie rozpatrzonych wniosków o nadanie statusu uchodźcy (wówczas było ich odpowiednio 348 i 262) ${ }^{53}$. Spadek ten należy tłumaczyć mniejszą liczbą cudzoziemców napływającą na teren Unii, o czym była już pokrótce mowa.

\section{Wnioski}

Problematyka dotycząca cudzoziemców nabiera obecnie szczególnego znaczenia. Jest tak z tego względu, że wciąż trwa kryzys migracyjny, który jest związany z masowym napływem uchodźców $z$ terenów Bliskiego Wschodu oraz Afryki Północnej. Próbując rozwiązać ten kryzys, rządy stosują różnorodne rozwiązania oraz procedury. Wśród nich są te, które dotyczą nadawania cudzoziemcom statusu uchodźców.

Status ten może otrzymać każda osoba, która wypełni kilka podstawowych warunków. Wśród nich jest przede wszystkim konieczność dowiedzenia przez cudzoziemca, że istnieje uzasadniona obawa przed możliwością objęcia go prześladowaniami w jego dotychczasowym kraju zamieszkania. Ponadto cudzoziemiec ten musi zostać zaliczony do kategorii uchodźców. Kategoria ta obejmuje osoby przebywające poza granicami państw, których są obywatelami, i niemogące bądź niechcące korzystać z ochrony oferowanej przez te państwa. Wówczas cudzoziemiec może zostać objęty ochroną międzynarodową w postaci nadania statusu uchodźców. Dzięki pozytywnemu rozpatrzeniu jego wniosku o taki status może on korzystać z wielu różnych praw, w tym

53 https://udsc.gov.pl/statystyki/raporty-okresowe/raport-roczny-ochrona-miedzynarodowa/2014-2/ (16.10. 2017). 
pobytu na terenie kraju docelowego, podejmowania pracy, odbywania nauki czy otrzymywania świadczeń socjalnych.

Z kwestiami dotyczącymi nadawania statusu uchodźcy może wiązać się szereg problemów praktycznych. Polegają one między innymi na nadużywaniu tej formy ochrony przez wielu cudzoziemców, dla których obawa przed prześladowaniami ma znacznie mniejsze znaczenie niż czynniki natury ekonomicznej, jak również na wielokrotnym składaniu wniosków o status uchodźcy przez jedną osobę. Z uwagi na obecny kryzys migracyjny w kilku ostatnich latach na terenie Unii znacznie wzrosła liczba wniosków, jak i pozytywnych decyzji o nadaniu statusu uchodźcy. Uwaga ta nie dotyczy jednak terenu Polski, gdzie wprawdzie w latach 2015-2016, w porównaniu z 2014 rokiem, znacznie wzrosła liczba złożonych wniosków o nadanie statusu uchodźcy, jednak liczba pozytywnych decyzji w omawianym okresie zmalała.

Podsumowując, zasadne jest stwierdzenie, że teza postawiona we wprowadzeniu do niniejszej pracy została w pełni potwierdzona. Zaznaczono bowiem, że status uchodźcy, obok ochrony uzupełniającej czy azylu, jest jedną z najważniejszych form międzynarodowej ochrony cudzoziemców i wykazano, że w przeciągu kilku ostatnich lat na terenie Polski i Europy coraz większa liczba cudzoziemców formułuje wnioski o uzyskanie takiej ochrony.

\section{Streszczenie}

W ramach podjętej tematyki przeanalizowane zostały zagadnienia, które są związane z praktycznym wykorzystywaniem przepisów dotyczących statusu uchodźcy, będącego jedną z prawnych form ochrony międzynarodowej dostępnej dla cudzoziemców. W artykule uwaga została skupiona przede wszystkim na wyjaśnieniu w jaki sposób międzynarodowe i polskie prawo podchodzi do kwestii związanych z definiowaniem uchodźcy, jak również jakie są warunki otrzymywania przez cudzoziemców statusu uchodźcy. W tym zakresie szczególną wagę mają rozważania odnoszące się do tego, o czym mówią klauzule włączenia i wyłączenia, za pomocą których możliwe staje się 
formułowanie przesłanek prowadzących do uznania danej osoby za uchodźcę, jak również klauzula ustania, dotycząca przypadków pozbawienia statusu uchodźcy. W pracy uwaga została zwrócona również na podjęcie próby określenia innych form ochrony międzynarodowej przewidzianych dla cudzoziemców i umiejscowienia wśród nich statusu uchodźcy. Ponadto ważne znaczenie miało omówienie kwestii dotyczących tego, jak na gruncie polskim wygląda procedura uzyskiwania przez cudzoziemców statutu uchodźcy, jakie formy pomocy mogą być im udostępniane oraz jaka liczba cudzoziemców korzysta $\mathrm{z}$ tego rodzaju ochrony.

Słowa kluczowe: cudzoziemcy, uchodźcy, status uchodźcy, ochrona międzynarodowa, prawo międzynarodowe, prawo polskie

\section{Summary}

The refugee status as a legal form of international protection for aliens

The paper analyses issues related to the practical application of refugee status regulations, which is a legal form of international protection available to aliens. The article focuses mostly on the approach of the international and Polish laws to the way the refugee is defined and on other conditions of granting the refugee status to aliens. Of particular importance in this regard is the discussion on the meaning of the inclusion and exclusion clauses that facilitate the determination of grounds for considering a person a refugee and on the cessation clause applicable to people who cease to be a refugee. Another focal point of the paper is the attempt to present other forms of international protection for aliens and find the place of the refugee status among them. The discussion on the Polish procedure for obtaining the refugee status by aliens, what forms of aid they can expect, and what number of aliens uses this type of protection was of importance as well.

Keywords: aliens, refugees, refugee status, international protection, international law, Polish law 
